\title{
The Ruined Castle
}

\section{Michael Rosen}

On the cover of Thom Brooks's admirable Hegel's Political Philosophy is a picture, taken by the author, of Tynemouth Castle, near where he lives on the northeast coast of England. It is an attractive image, yet it also has significance in relation to the argument of his book -one that only emerges at the end of his narrative.

A basic question that faces all interpreters of The Philosophy of Right is: how far must we understand Hegel's views on politics in the light of his wider philosophical commitments? Behind that question lies a very simple argument:

(1) If we take Hegel at his word, and his political philosophy is indeed integrated within his broader philosophical system; and,

(2) if that philosophical system is a consistent realization of speculative idealism; then

(3) everything will depend on how we evaluate speculative idealism.

Hegel's ambitious metaphysics now finds few defenders, however. So, does his political philosophy fall with it?

To this there are two kinds of reply. The first would make a separation between the political doctrines advanced in Hegel's work and the philosophical framework within which they are embedded. The second, while accepting that Hegel's philosophy is meant to form an integrated whole, disputes the idea that, for that reason, the "dialectical" treatment of particular areas of life and experience depends on our final verdict on the system as a whole. It is possible to enter his system at any point and to continue piecemeal, treating its arguments on their own terms without concern for its final resting point. Against this, Brooks argues that the piecemeal approach fails to do justice to Hegel's text.

To summarise his objections, as I understand them, the problem is that of justification. Brooks cites a number of general statements by authors who take a less systematic view. Thus Robert Pippin remarks that, 'without any systematic attempt to rely on the incredibly opaque details of the Science of Logic', Hegel's claims can be discussed 'as independently valuable insights' (Brooks 2007: 8). Likewise, Steven Smith thinks that it is possible to salvage Hegel's 'useful political insights' from their 'speculative wrappings' (Brooks 2007: 9). That Pippin and Smith both talk in such non-committal terms about Hegel's 'insights' seems revealing — as if they were too cautious to claim that Hegel has arguments independent of his speculative philosophy that command our assent.

Yet that, surely, is what is needed. It is one thing to advance this or that political view — that the state should be organised as a constitutional monarchy, that there should 


\section{Michael Rosen}

be a regime of private property, that capital punishment for murder is mandatory, and so on- it is another to say why one should accept such a view. Hegel's ideas about how the state should be organised are neither so strikingly original nor so immediately appealing that we would value them without supporting argument, and this pushes us back to the issue raised earlier. Does Hegel offer persuasive grounds for taking the positions that he does?

The justifications that Hegel presents often appear to consist in simply showing how individual features of the realised state mirror the structures of The Science of Logic a feature of his text that has been noticed and criticised by readers since (at least) Karl Marx: 'Hegel's true interest is not the philosophy of right but logic.... Logic is not used to prove the nature of the state, but the state is used to prove the Logic' (Marx 1970: 18).

This correspondence between politics and logic ('Logic', of course, in Hegel's special, metaphysical sense of the term) is certainly deliberate; Hegel himself points to it in the Zusatz, to $\$ 279$, 'The state must be treated as a great architectonic structure, as a hieroglyph of the reason that reveals itself in actuality'. Hegel repeatedly asserts the existence of a connection between the philosophical understanding of politics and speculative philosophy in the course of the book. Take, for example, the transition from Moralität to Sittlichkeit at the end of \$141. The details of this transition of the concept, Hegel writes, are 'made intelligible in logic'. He then offers two paragraphs of what Pippin might well regard as 'incredibly opaque details' about one-sided conceptions not yet being posited in accord with their implicit nature, from which he draws the conclusion that Sittlichkeit is the truth of the concept of freedom, 'something which, in philosophy, must be proved, not presupposed, not adopted from feeling or elsewhere'. Proof of this kind is essential, says Hegel:

Those who hope to be able to dispense with proof and demonstration in philosophy show thereby that they are still far from knowing the first thing about what philosophy is. They may argue on other topics, but in philosophy they have no right to join the argument if they wish to argue without the concept. (PR 104, \$141 Zusatz)

Philosophical demonstration of this kind takes priority over empirical fact. Philosophical procedure requires, Hegel asserts in the discussion of method in the Zusatz, to \$32, that 'we merely look on as the concept determines itself. We acquire thereby both 'a series of thoughts and another series of existing forms'. It may happen that these two series fail to correspond; that the 'order of the concept' and 'the time-order in real appearance' differ (as in the case of the family and private property). In this case, however, it is the 'order of the concept' that is essential, not the empirical reality within which it is realised — 'that which is actual, the form of the concept, is thus for us the secondary and succeeding element, even if it is prior in reality' (PR 35, \$32 Zusatz). 


\section{The Ruined Castle}

Brooks follows his theme through in a series of accounts of some of the most widely discussed topics in The Philosophy of Right - property, punishment, the nature of law, the family, the monarchy and the external relations between states. Although one might quarrel with this or that detail, he establishes conclusively to my mind that Hegel's positions are only fully intelligible within the wider framework of his conception of philosophy. Yet that, of course, brings us back to the question with which I started: does the value of Hegel's political philosophy fall with his metaphysics? Nor does Brooks shirk an answer - it comes with the image of the ruined castle. Like an ancient monument, he concludes, we can value Hegel's political philosophy, re-construct its structure and place it in the context of a past way of life, without imagining that we should (or could) live in it today.

Since I strongly agree with Brooks's overall position, I shall use the rest of this contribution to reflect a little more on what this might mean.

Let us accept that the castle is in ruins - there is no roof and there are holes in the walls. But, castles, even at their best, are damp and draughty. If you don't have to keep out marauding Vikings, would you want to live in one anyway? In other words, even if it is possible to repair Hegel's system sufficiently to sustain his political philosophy, would it really be desirable to do so?

In the first part of the twentieth century, the prevailing attitude towards Hegel's political philosophy in the Anglo-Saxon countries was fiercely critical. Hegel was identified with a characteristically Germanic (as it was thought) state-worship, held to be responsible, at least in part, for two world wars.

Certainly, there are passages in The Philosophy of Right (the state is 'der Geist der in der Welt steht (\$270), an 'irdisch-göttliches' (\$272, Zusatz), 'die Weltgeschichte ist das Weltgericht' (\$340) and so on) that seem to point in that direction. But, as readers returned to Hegel in a calmer spirit, they pointed to themes that ran counter to that caricature.

Most clearly, there are Hegel's repeated assertions that, at the heart of the modern state (in contrast to the ancient polis) lie the twin principles of the equality of all human beings and the right of citizens to an independent sphere of private life, immune from public requirements. This, surely, is enough to separate Hegel from the elitist racism and the absorption of the individual by a militarized state-machine that underpinned the fascist nightmare.

Yet later interpreters have gone further. At the heart of Hegel's account of politics is, they point out, the value of freedom; 'the system of right is the realm of freedom made actual, the world of Geist produced from itself as a second nature' (PR 20, \4). Hence, so far from being a picture of politics in which the individual submits to the will of the collective, Hegel, for some modern interpreters, is giving us an account of how individuals may realise themselves within a collective order while still holding fast to freedom and equality. Add in the modern 'obstinacy', praised by Hegel, that 'will not recognise anything in conviction that is not justified through thought' ('durch den Gedanken gerechtfertigt (PR Vorrede 27) and it is possible to read Hegel, amazingly enough, as a 


\section{Michael Rosen}

precursor of Rawls's 'Idea of Public Reason'. (Rawls himself, in his remarkably sympathetic lecture discussion of Hegel describes him as 'a moderately progressive reform-minded liberal' (Rawls 2000: 349).

But, if this is so, why is it that —as Brooks establishes conclusively, to my mindHegel's own institutional prescriptions are far from those we expect from 'moderately progressive reform-minded liberals' nowadays? His rejection of democracy is an obvious difference, of course, but it is not, I think, the most significant - there are, after all, many respectable ways to argue that democracy is not the best form in which the values of freedom and equality can be institutionally realised. More revealing, I think, is how Hegel handles the issue of legitimation.

Hegel says in the Zusatz to $\$ 317$ that 'The principle of the modern world requires that what anyone is to recognise shall reveal itself to him as something entitled to recognition'. In other words, it seems, Hegel is endorsing the principle of 'justifiability to each person', often taken as the essential core of modern political liberalism. Yet justifiability is an elusive idea —and it returns us to the problem raised earlier. If people are entitled to have the political order justified to them and the justification of the modern state is given by speculative philosophical Wissenschaft, do we have to give all the state's citizens classes in Hegelian philosophy?

Bearing this in mind, Hegel's remarks on compliance and dissent are significant. Consider the long Zusatz to $\$ 270$ in which Hegel discusses the role of religion in the state:

Now if you say that the state must be grounded on religion, you may mean that it should rest on rationality and arise out of it; but your statement may also be misunderstood to mean that men are most adroitly schooled to obedience if their minds are shackled by a slavish religion .... But if you mean that men ought to respect the state, this whole whose limbs they are, then of course the best means of effecting this is to give them philosophical insight into the essence of the state, though, in default of that, a religious frame of mind may lead to the same result (PR \$270 Zusatz 166, my emphasis)

So yes, indeed, Hegel does, apparently, think that philosophy is the ideal means of justification. But note too that the problem as Hegel here poses it has significantly shifted. It isn't: how can we rationally justify the state to individuals?, so much as: how do individuals come to see the state as worthy of respect? In other words, we've moved from justification in the form of rational demonstration to each citizen to the conditions for citizens' de facto compliance. And this leads to tensions. We can see them very clearly in the discussion of public opinion in $\$ 317$ (the very section in which Hegel asserts the principle of justifiability, as we have seen). 'Public opinion', he writes: 


\section{The Ruined Castle}

is a repository not only of the genuine needs and correct tendencies of common life, but also, in the form of common sense (i.e. all-pervasive ethical principles disguised as prejudices), of the eternal, substantive principles of justice, the true content and result of legislation, the whole constitution and general position of the state. At the same time, when this inner truth emerges into consciousness and, embodied in general maxims, enters immediate representation [Vorstellung] ... it becomes infected by all the accidents of opinion, by its ignorance and perversity, by its mistakes and falsity of judgement (PR 204 \$317).

For that reason, Hegel concludes, public opinion deserves to be both 'respected' and 'despised' (\$318). To put it briefly: full rational justification comes from philosophy and is freely available - but only to those who understand (and endorse) speculative Logic; de facto justification is sociologically inherent to the rational state at an essential level; dissent from that state (opposition, say, to its centralised, top-down political structure, economic inequality and complacent attitude towards war and conflict) is merely superficial and phenomenal and need not be given weight. Some 'reform-minded liberal', eh?

But my aim here is not to mount a polemic against Hegel — there have been more than enough of those. (If you detect a note of exasperation in the last paragraph it is directed at the superficiality of post-Rawlsian apologists for Hegel, unsystematically cherry-picking his apparently individualistic and pluralistic statements.) My purpose is not to come down on one side or the other but to make the point - what one would have hoped would be the blindingly obvious point - that both sides of Hegel are essential to him.

On the one hand, Hegel gives us an account of the modern self drawing on Luther and Kant. On this account, equality and private self-assertion are essential parts of modernity, not the corrosive threats to social unity that the Romantic conservatives of Hegel's own day had depicted them as being. On the other, we have what I call Hegel's 'sociological idealism' - the idea that all cultures contain within themselves an inner principle of unity that holds them together and that determines their growth and decay:

the constitution adopted by a people makes one substance - one spirit - with its religion, its art and philosophy, or, at least, with its conceptions and thoughts - its culture [Bildung] generally; not to expatiate upon the additional influences, ab extrâ, of climate, of neighbours, of its place in the world. A state is an individual totality, of which you cannot select any particular side, although a supremely important one, such as its political constitution; and deliberate and decide respecting it in that isolated form (LPH §47).

What holds societies together is a 'general will' that exists at a level more deep than the kind of justification by reference to individual self-interest required by rationalist 


\section{Michael Rosen}

liberalism. This collective, objective spirit, rooted ultimately in an organicist metaphysics, pervades all persisting societies, even the most authoritarian:

The origin of a state involves imperious lordship on the one hand, instinctive submission on the other. But even obedience - lordly power, and the fear inspired by a ruler - in itself implies some degree of voluntary connection. Even in barbarous states this is the case; it is not the isolated will of individuals that prevails; individual pretensions are relinquished, and the general will is the essential bond of political union (LPH \47).

So, to return in conclusion to Brooks's castle. It isn't just that the culminating point of Hegel's philosophy — his speculative logic — is beyond repair. It is that it is only by means of the idealistic metaphysics that that Logic (allegedly) justifies that the two very different but equally essential sides of Hegel's political project - the vindication of modern individuality and the depiction of states as inherently cohesive manifestations of an underlying, organic unity - can be held together. And, while the first part may be sympathetic to modern, egalitarian liberals, and the second attractive to anti-rationalist conservatives of a Burkean or Oakeshottian spirit, we should abandon the idea of realizing both together. Better leave it to stand as a magnificent monument from a bygone age.

\section{Michael Rosen}

Department of Government

Harvard University

rosenme@gmail.com

\section{Bibliography}

G.W.F.Hegel (1970), Grundlinien der Philosophie des Rechts. Frankfurt a.M., Suhrkamp translations are by T.M. Knox, modified by the author, abbreviated as PR

G.W.F. Hegel (1970) Vorlesungen über die Philosophie der Geschichte. Frankfurt a.M., Suhrkamp - translations are by the author, abbreviated as LPH

Marx, K. (1970) Critique of Hegel's Philosophy of Right. Translated by A. Jolin and J.

O’Malley. Cambridge: Cambridge University Press.

Rawls, J. (2000), Lectures on the History of Moral Philosophy. Cambridge, MA: Harvard University Press 